\title{
Severe Pseudocholinesterase Deficiency and ECT: a Case Report
}

\section{Eren Yildizhan ${ }^{1}$, Nesrin Buket Tomruk ${ }^{10}$ Hafize Miray Aytac ${ }^{10}$ Hakan Yildirim ${ }^{2 \bullet}$, Ozge Canbek ${ }^{1 \oplus}$ \\ 'Bakirkoy Research and Training Hospital for Psychiatric and Neurological Diseases, Department of Psychiatry, Istanbul - Turkey \\ ${ }^{2}$ Bakirkoy Research and Training Hospital for Psychiatric and Neurological Diseases, Department of Anesthesiology, Istanbul - Turkey}

\section{ABSTRACT}

Severe pseudocholinesterase deficiency and ECT: a case report

Pseudocholinesterase (PCE) deficiency is an inherited condition in which recovery from anesthetic agents like succinylcholine and mivacurium is slow and complicated by prolonged paralysis of respiratory muscles in susceptible patients. We present a very rare case of a 29-year-old woman with a 15-year history of schizophrenia with pseudocholinesterase deficiency that we encountered in our practice. Since the measurement of PCE levels of all patients eligible for ECT is part of our pre-ECT assessment procedure, we could detect the deficiency before the ECT procedure. We performed modified ECT with propofol and rocuronium instead of succinylcholine as usual. Sugammadex was used for speeding up the recovery. Response to treatment as measured by the Positive and Negative Symptom Scale was good and we completed 9 ECT sessions without complication. We suggest further investigation of this topic because screening for PCE levels in pre-ECT assessment may reduce complications of modified ECT with anesthesia. Keywords: Electroconvulsive therapy, mivacurium, pseudocholinesterase deficiency, schizophrenia, succinylcholine, sugammadex

\section{Öz}

Şiddetli pseudokolinesteraz eksikliği ve EKT: Bir olgu sunumu

Pseudokolinesteraz eksikliği, eksikliğin görüldüğü hastalarda, suksinilkolin ve mivakuryum gibi anestezi ajanlardan uyanmanın yavaş olduğu ve solunum kaslarının paralizinde uzamaya neden olabilen kalıtımsal bir durumdur. Klinik uygulamamız sırasında karşılaştığımız nadir bir olgu sunmaktayız: 15 ylllık şizofreni öyküsü bulunan ve pseudokolinesteraz eksikliği olduğunu saptadığımız 29 yaşında bir kadın hasta. PCE seviyelerinin tespiti EKT adayı bütün hastalarımızda yaptığımız rutin bir işılem olduğundan, eksikliği EKT uygulamasına başlamadan tespit edebildik. Modifiye EKT'yi suksinik kolin yerine propofol ve rokuronyum ile uyguladık. Uyanmayı hızlandırmak için sugammadex kulanıldı. Pozitif ve Negatif Belirti Ölçeği ile kaydedilen tedaviye yanıt olumluydu ve 9 EKT seansını komplikasyonsuz olarak tamamladık. EKT öncesi tetkiklerin içine pseudokolinesteraz düzeyinin konulmasının, araştıııması gereken bir konu olduğunu ileri sürmekteyiz çünkü bu yöntem anestezili modifiye EKT komplikasyonlarını azaltabilir.

Anahtar kelimeler: Elektrokonvulziv tedavi, mivakuryum, pseudokolinesteraz eksikliği, şizofreni, suksinilkolin, sugamadeks

How to cite this article: Yildizhan E, Tomruk NB, Aytac HM, Yildirim H, Canbek O. Severe pseudocholinesterase deficiency and ECT: a case report. Dusunen Adam The Journal of Psychiatry and Neurological Sciences 2018;31:312-315. https://doi.org/10.5350/DAJPN2018310311

\section{INTRODUCTION}

P seudocholinesterase (PCE) deficiency is a condition in which butyrylcholinesterase - the enzyme responsible for the breakdown of butyrylcholine - is deficient. Agents such as succinylcholine, mivacurium, and ester-linked local anesthetic compounds are also subject to breakdown by this enzyme (1). Main outcome of the condition is prolonged paralysis and apnea after anesthetic procedures. The deficiency can be acquired or genetic. Liver disease, renal disease, malnutrition, pregnancy, hepatic or gastrointestinal malignancies, and burns are some of the conditions responsible for acquired PCE deficiency (2). Types of genetic deficiency are dibucaine-resistant $(0.01-0.03 \%)$, fluoride-resistant $(0.0007 \%)$, and silent $(0.008-0.01 \%)$ 
variants (respective frequencies are given in parenthesis). There is also the Kalow $(\mathrm{K})$ variant with a frequency of $1.5 \%$ that has minimal clinical significance, in which there is only a $30.0 \%$ reduction in enzyme activity (3).

Succinylcholine has been used as a muscle relaxant during electroconvulsive therapy (ECT) since the 1950s (3). Although it has a diverse side effect profile, including myalgia, cardiac arrhythmias, increased intracranial pressure, hyperkalemia, and malignant hyperthermia, it is used frequently in ECT procedures due to its short incubation period $(4,5)$. Prolonged apnea after succinylcholine administration is also a problematic phenomenon after the ECT procedure. Anoxia, aspiration, and cardiac arrhythmias are some of the possible complications of apneic periods (4).

In our hospital, ECT has been applied with anesthesia since 2006 and succinylcholine is the muscle relaxant of choice in the ECT sessions, like in most similar clinics in Turkey (6-9). Detection of patients' serum pseudocholinesterase levels is part of our routine preoperative laboratory workup. We present a very rare case that we encountered in our practice: a severe PCE deficiency that could have complicated the modified ECT procedure if necessary precautions had not been taken.

\section{CASE}

H.D. was a 29-year-old, single Caucasian female patient with a history of schizophrenia. Her weight was $80 \mathrm{~kg}$. She had 5 years of primary school education and no history of employment. She was admitted to our inpatient clinic because of hostility and irritability. She believed that there were defamatory comments about her on television.

Her first psychotic episode had happened when she was 13 years old, and she was diagnosed with early-onset schizophrenia in the child psychiatry department. Haloperidol, chlorpromazine, and zuclopenthixol decanoate were the first antipsychotics she had been prescribed. During a period of 15 years, she had undergone 30 psychiatric hospitalizations, approximately 2 times per year, warranting a diagnosis of treatment-resistant schizophrenia. She had a history of ECT without anesthesia in another clinic previously, but she had not received modified ECT with anesthesia and muscle relaxants until her index hospitalization.

In the psychiatric ward, she was very reluctant to talk to the medical staff. Psychiatric examination revealed lack of self-care, increased psychomotor activity, auditory hallucinations, and delusions of reference and persecution. She was fully oriented. Physical and neurological examinations were normal. Her psychiatric symptom severity was evaluated with the Positive and Negative Syndrome Scale (PANSS), with an initial total score of 148 (PANSS positive: 41; PANSS negative: 38; PANSS general: 69). Blood workup was normal except for vitamin B12-deficiency anemia, and she was given cyanocobalamin 1000mg intramuscularly twice a day for 5 days. She was given haloperidol $20 \mathrm{mg} / \mathrm{day}$, biperiden $10 \mathrm{mg} / \mathrm{day}$ intramuscularly and quetiapine $400 \mathrm{mg} /$ day orally. Since she did not respond to the initial treatment, quetiapine was stopped; chlorpromazine $50 \mathrm{mg} /$ day intramuscularly and lorazepam $7.5 \mathrm{mg}$ /day orally were added to her treatment.

Because of continuous aggressive excitations with homicidal risk and paranoid thought content, ECT was indicated, and consent was obtained from the family member who was the patient's legal representative. When we checked for the PCE level as part of the pre-ECT workup, we detected severe PCE deficiency (PCE level: 126IU/L; normal values of PCE are between 3200 and 6600IU/L). Lorazepam was stopped 3 days before the first ECT session, since it has a propensity to increase seizure threshold. The patient was given haloperidol $20 \mathrm{mg} /$ day, biperiden $10 \mathrm{mg} / \mathrm{day}$, chlorpromazine $50 \mathrm{mg} / \mathrm{day}$, and zuclopenthixol $50 \mathrm{mg}$ once intramuscularly during the 3 -week period of ECT. Modified ECT with anesthetic and muscle relaxant was applied with a frequency of three sessions per week. Rocuronium 25mg was used intravenously as a muscle relaxant instead of succinylcholine. Propofol 60mg intravenously was used as the anesthetic compound. A Thymatron System IV (Somatics, LCC, Lake Buff, III) integrated 
ECT instrument was used. Bilateral ECT was applied with bifrontotemporal electrode placement. Sugammadex $100 \mathrm{mg}$ was given intravenously to shorten the recovery phase after the convulsion had stopped. The patient's oxygenation was monitored during the sessions. ECT sessions were uneventful. Dramatic improvement was observed in the patient's hostility after the $4^{\text {th }}$ ECT session, resulting in a 30-point decline in total PANSS score (PANSS positive: 33; PANSS negative: 33; PANSS general: 52). Nine ECT sessions were conducted successfully without complications. Five days after the last ECT, PANSS total score was 67 (PANSS positive: 12; PANSS negative: 22; PANSS general: 33). Chlorpromazine, which was started with $50 \mathrm{mg}$ daily intramuscularly, was switched to oral treatment and was titrated up to $500 \mathrm{mg}$ daily. When improvement of the delusions of persecution and reference was observed, we discharged the patient to be followed up in the outpatient clinic with a treatment of chlorpromazine 500mg/day, haloperidol 20mg/day, biperiden $4 \mathrm{mg} /$ day, and zuclopenthixol decanoate 200mg biweekly.

\section{DISCUSSION}

The percentage of ECT-treated patients in our center $(14.4 \%)$ is higher than the rate reported in Western centers, similar to most Asian countries and lower than in African countries $(6,7)$. In our hospital, the most frequent diagnosis in ECT-treated patients was bipolar affective disorder, but when treatment resistance or imminent suicidal or homicidal risk was apparent, ECT was also performed frequently in patients with schizophrenia (6). In adolescent and young adult patients in first-episode psychosis, ECT was seldom used (10). In our hospital, 24310 patients were hospitalized for acute conditions within 3 years, and 3490 of these patients were treated with ECT (6). The PCE level of the patient in the case outlined above was the lowest of the values we have ever detected in our ECT center, and as far as we know it was the lowest value reported in the ECT literature (2).
Propofol, thiopental, and etomidate are anesthetic agents that we use during ECT sessions; safety and effectiveness of ECT with these agents were reported in a previous study (11). We usually use succinylcholine $(0.5 \mathrm{mg} / \mathrm{kg})$ as a muscle relaxant in ECT sessions. Since we had detected the patient's severe PCE deficiency, we used rocuronium - a non-depolarizing muscle relaxant - instead of succinylcholine. Prolonged apnea is an expected problem when succinylcholine is used in ECT in cases of PCE deficiency and mechanical ventilation is needed continuously until the succinylcholine paralysis ends (2). The availability of sugammadex enables the rapid termination of the muscle blockade effected by rocuronium.

Thanks to the detection of PCE levels is part of our pre-ECT assessments, it was possible for us to select rocuronium as the muscle relaxant to prevent complications. We did not detect any acquired cause for the PCE deficiency in our case, so we can conclude that it was a genetic variant of PCE deficiency. Although there is a low prevalence of clinically significant genetic PCE deficiency, there are also acquired cases of PCE deficiency. Chronic psychotic patients are at increased risk for malnutrition; the use of polypharmacy increases the risk of hepatic and renal diseases, and cardiovascular events are also seen with increased prevalence in these patients. Therefore, we can also expect the incidence of acquired cases of PCE deficiency to be increased in these patients compared to the general population. Thus we suggest the detection of PCE levels to be a part of routine preECT laboratory assessments.

\begin{tabular}{|l|l|l|}
\hline \multicolumn{1}{|l|}{ Contribution Categories } & Author Initials \\
\hline \multirow{4}{*}{ Category 1} & Concept/Design & E.Y., N.B.T. \\
\cline { 2 - 3 } & Literature review & E.Y. \\
\cline { 2 - 3 } & Data analysis/Interpretation & H.Y., O.C., H.M.A. \\
\cline { 2 - 3 } & Case follow-up (if applicable) & E.Y., H.M.A. \\
\hline \multirow{3}{*}{ Category 2} & Drafting manuscript & E.Y., H.M.A., O.C. \\
\cline { 2 - 3 } & Critical revision of manuscript & N.B.T., H.Y. \\
\hline \multirow{3}{*}{ Category 3} & Final approval and accountability & E.Y., N.B.T., H.M.A., H.Y., \\
\hline \multirow{3}{*}{ Other } & Oechnical or material support & N/A \\
\cline { 2 - 3 } & Supervision & N/A \\
\cline { 2 - 3 } & Securing funding (if applicable) & N/A \\
\hline
\end{tabular}


Informed Consent: Written consent was obtained from the participants.

Peer-review: Externally peer-reviewed.

\section{REFERENCES}

1. Soliday FK, Conley YP, Henker R. Pseudocholinesterase deficiency: a comprehensive review of genetic, acquired, and drug influences. AANA J 2010; 78:313-320.

2. Williams J, Rosenquist $\mathrm{P}$, Arias L, McCall WV. Pseudocholinesterase deficiency and electroconvulsive therapy. J ECT 2007; 23:198-200. [CrossRef]

3. Churchill-Davidson HC. Suxamethonium (succinylcholine) chloride and muscle pains. Br Med J 1954; 1:74-75. [CrossRef]

4. Saricicek V, Gul R, Dogan M, Koruk S, Goksu S. Use of rocuronium-sugammadex in patient who prolonged apnea due to pseudocholinesterase deficiency during ECT. Journal of Turgut Ozal Medical Center 2013; 20:364-366. (Turkish)

5. Allen TK, Habib AS, Dear GL, White W, Lubarsky DA, Gan TJ. How much are patients willing to pay to avoid postoperative muscle pain associated with succinylcholine? J Clin Anesth 2007; 19:601-608. [CrossRef]

6. Canbek $\bigcirc$, Menges $\bigcirc$, Atagun MI, Kutlar MT, Kurt E. Report on 3 years' experience in electroconvulsive therapy in Bakirkoy Research and Training Hospital for psychiatric and neurological diseases: 2008-2010. J ECT 2013; 29:51-57.
Conflict of Interest: Authors declared no conflict of interest.

Financial Disclosure: Authors declared no financial support.

7. Saatcioglu $\bigcirc$, Tomruk NB. Practice of electroconvulsive therapy at the research and training hospital in Turkey. Soc Psychiatry Psychiatr Epidemiol 2008; 43:673-677. [CrossRef]

8. Yildiz A, Gokmen N, Turgut K, Yucel G, Tunca Z. Place of electroconvulsive therapy among the somatic treatments in a university clinic psychiatric inpatients. Bulletin of Clinical Psychopharmacology 2003; 13:65-71. (Turkish)

9. Zeren T, Tamam L, Evlice YE. Electroconvulsive therapy: assessment of practice of 12 years' period. New Symposium 2003; 41:54-63. (Turkish)

10. Yildizhan E, Turkcan A, Inan S, Erenkus Z, Yalcin O, Erdogan A. First episode psychosis: relationship of symptoms, initial treatment and clinical response. Turk Psikiyatri Derg 2015; 26:77-86.

11. Canbek O, Ipekcioglu D, Menges OO, Atagun MI, Karamustafalioglu N, Cetinkaya OZ, Ilnem MC. Comparison of propofol, etomidate, and thiopental in anesthesia for electroconvulsive therapy: a randomized, double-blind clinical trial. J ECT 2015; 31:91-97. [CrossRef] 